\title{
The historical micro-narrative as an Instrument in the formation of collective identity and memory The symbolic and ideological dimension of the visit of Štúr's group to Ján Hollý at Dobrá Voda
}

\author{
PETER M A C HO
}

\begin{abstract}
MACHO, Peter. The historical micro-narrative as an Instrument in the formation of collective identity and memory. The symbolic and ideological dimension of the visit of Štúr's group to Ján Hollý at Dobrá Voda. Historický časopis, 2018, 66, 5, pp. 849-884, Bratislava.

The study analyses the structural elements of the story of the visit of Štur and two of his followers to the poet Ján Hollý. The meeting of representatives of the Protestant and Catholic intelligentsia in 1843 was a key moment in the Slovak national historical narrative. It symbolizes national unity overcoming confessional limitations. The author studies this story as part of the nationalist repertoire, pointing to its use for the needs of national ideology.

Key words: History of Slovakia in the $19^{\text {th }}$ and $20^{\text {th }}$ centuries. Slovak nationalism. National story. Standard written language. Catholics and Protestants. Ján Hollý. L’udovít Štúr. Jozef Miloslav Hurban. Andrej Kováčik.

DOI: https://doi.org/10.31577/histcaso.2018.66.5.3
\end{abstract}

Modern Slovak nationalism was shaped under the long-term influence of the two main churches or confessions: Roman Catholic and Evangelical - Lutheran Protestant. Other churches or denominations also understandably existed and functioned in the northern part of the historic Kingdom of Hungary, which can be approximately identified with present-day Slovakia, but they were not relevant to the shaping of the Slovak national narrative and symbolism. Since the Slovaks were a nation without significant constitutional traditions, their language became their main ethno-identifying element and national symbol. The search for a concrete form of standard written language was a relatively complicated process, which struck against the barriers of linguistic practice applied in the liturgical life of the two churches. The first attempt at codification of a written language on the basis of the western Slovak dialect or interdialect happened at the end of the $18^{\text {th }}$ century in the environment of the Catholic scholars of the Enlightenment generation. The main initiator and protagonist of this codification process was the Catholic priest Anton Bernolák, who compiled a grammar and dictionary. 
However, Bernolák's form of the standard written language became established only in the environment of the Catholic intelligentsia, while Evangelical intellectuals continued to use for cultural purposes their liturgical language: Czech. Some of them, such as Ján Kollár endeavoured to establish a hybrid form of Czecho-Slovak language or Czech with Slovak elements. However, the situation changed with the coming of the Romantic generation. In the 1840s, they came mainly from the ranks of the young members of the Protestant intelligentsia led by L'udovít Štúr and formed a group known as the "Štúrovci" in Slovak. They gradually abandoned Czech but did not join the adherents of Bernolák's Slovak. Instead, they began to use a new form of the Slovak language.

Various factors contributed to this decision. Among them, it is possible to mention the search for the ideal form of the national language, which was associated with Herder's myth of the centre. The national narrative came to include the idea that Slovakia or the Slovaks and their language represent the geographical and linguistic centre of the Slavonic peoples with the Tatra mountain region as the cradle of all the Slavs and the Slovak language as the mother of all the Slavonic languages. ${ }^{1}$

The literary historian and semiotic theorist Vladimír Macura points to the fact that in the Czech and Slovak environment the idea of the centre served especially the topical need of evaluation of European nations and languages: presence in the centre, the central position of a language, nation or linguistic phenomenon became a feature to be evaluated positively. ${ }^{2}$ In other words, a phenomenon situated in a central position or found in the centre showed exceptional quality or was considered ideal in the reflection of members of the so-called patriot elite.

Štúr's group chose the central Slovak dialect or inter-dialect as the basis for their new standard written language. In the context of the myth about the Slavonic centre, this dialect was understood and presented as the best preserved and purest form of Slovak, but also as an imaginary Slavonic language. In this linguistic ideological concept, central Slovak represented the most central cen-

1 We also encounter this view in the thinking of J. Kollár: "Up to now the Carpathian Slovaks had hardly any of their own literature [understand: strong literary production and tradition - note P.M.], so they were the first to stretch out their hands to embrace all the Slavs. Their dialect stands grammatically and geographically in the centre of all the Slavonic dialects: because the Carpathians and the Tatras are and remain the cradle of the Slavs. Therefore, the Slovaks in the Kingdom of Hungary most enthusiastically grasped the idea of [Slavonic] community and spread it most widely and deeply, although it did not originate among them." Cited according to the edition KOLLÁR, Ján. O literárnej vzájomnosti. (On literary community). Bratislava 1954, p. 121-122.

2 MACURA, Vladimír. Herderovský ,pojem středu“ v myšlení jungmannovské generace. (Herder's concept of the "centre" in the thinking of Jungmann's generation). In Slavia, 1975, year 45 , no. 2 , p. 143-150. 
tre, the central point of Slavdom. It meant a return to the true original source, to the root. ${ }^{3}$ The historian L'ubomír Lipták mentions that the choice of the central Slovak dialect as the basic starting point for the new codification was decided not only by mythic ideas, but also by more rational and pragmatic considerations such as inter-regional communication and integration: "The previous stages of the national movement were mostly geographically limited, and anchored mainly in western Slovakia. One of reasons why L. Štúr chose central Slovak as the basis for the standard written language was the idea of its function as a connecting link with the nationally unawakened eastern Slovaks. The Tatras would have a unifying function. Symbolically speaking, the whole of Slovakia could be seen from them, and they were visible from the whole of Slovakia." 4

$$
* * *
$$

The Czech historian Eduard Maur in the framework of a publication about collective memory stresses that fact that supporters of various research traditions and concepts - whether concerning historical knowledge and consciousness, collective memory, myth or tradition - come to the same conclusion, namely that these phenomena fulfil essentially the same functions: "They serve not only to organize the chaotic fragments of individual knowledge and ideas about the past into a meaningful whole, but [...] they are also significant instruments for constituting the identity of a given community and strengthening its solidarity, $[\ldots]$ they have the same legitimizing function (whether in the sense of confirming the existing state, institutions, structures and authorities, or as a support for demanding change to them). They relate to certain values, which members of the given community consider or are supposed to consider important, and which are understood as in some way normative for the future. It is the same with the personalities or events that embody these values."

3 MACHO, Peter. Od pravlasti ku koliske, od Karpát ku Tatrám. Mýtus slovanského stredu v kontexte vývoja slovenskej národnej identity a ideológie. (From original homeland to cradle, from the Carpathians to the Tatras. The myth of the Slavonic centre in the context of the development of Slovak national identity and ideology). In HOJDA, Zdeněk - OTTLOVÁ, Marta - PRAHL, Roman (eds.). "Slavme slavně slávu Slávóv slavných.” Slovanství a česká kultura v 19. století. (Sborník příspěvků z 25. ročníku sympozia k problematice 19. století, Plzeň, 24. - 26. února 2005). Praha: Koniasch Latin Press, 2006, p. 240-257. ISBN 8086791327

4 LIPTÁK, L’ubomír. Tatry v slovenskom povedomí. (The Tatras in Slovak consciousness). In Slovenský národopis, 2001, year 49, no. 2, p. 148.

5 MAUR, Eduard. Památná místa: Místa paměti ve vlastním (t. j. topografickém) smyslu slova. (Memory places: Places of memory in the true (i.e. topographical) sense of the word). In MASLOWSKI, Nicolas - ŠUBRT, Jiří a kol. Kolektivní pamět'. K teoretickým otázkám. Praha: Univerzita Karlova v Praze; Nakladatelství Karolinum, 2014, p. 143. ISBN 9788024626895. 
According to Maur, researchers also agree on the view that in the case of collective ideas about the past, it is a matter of phenomena that are to a large extent constructed, "in a deliberate, planned way as a result of targeted political memory, which exploits memory in a manipulative way to achieve a desired result". ${ }^{6}$

In this study I will not consider only the factographic aspect of the specific historic events of the visit of three members of the Romantic generation to the important Slovak poet Ján Hollý at Dobrá Voda in 1843. I have taken just as much interest in the answer to the question of how and why this event and the course of this historical micro-narrative became part of the collective memory, which influenced and still influences the national identity of the Slovaks. Thus my consideration of this problem is in some ways closer to the anthropological than to the traditional historiographic understanding. For example, the difference between these two approaches is described by the social anthopologist T. H. Erikson: "While many historians have a tendency to strive to find out what really happened [...], the majority of anthropologists would rather direct their attention to clarifying the methods by which specific historical narratives are used as instruments for the formation of identities and for political purposes."

The story of how Ludovít Štúr and his friends or associates Jozef Miloslav Hurban and Michal Miloslav Hodža visited the poet Ján Hollý at Dobrá Voda on 17 July $1843,{ }^{8}$ is a very well-known historical episode: We know it was school textbooks, from artistic and publicist presentations, and from historiographic lectures. In this context it is also possible to point to the artistic versions of this theme such as the well known oil painting by Andrej Kováčik of the Visit of Šturr, Hurban and Hodža to Ján Hollý at Dobrá Voda in July $1843 .{ }^{9}$

Jozef Miloslav Hurban described this visit in his biography of Ludovít Štúr with the following words: "Then we undertook a joint visit to the master of Slovak poets Holly' at Dobrá Voda with the aim of showing our respect in person and offering him an explanation of our deviation from his method of writing in

6 MAUR, ref. 5, p. 143.

7 ERIKSEN, Thomas Hylland. Etnicita a nacionalismus. Antropologické perspektivy. (Ethnicity and nationalism. Anthropological perspectives). Praha: Sociologické nakladatelství, 2012, p. 124. ISBN 9788074190537.

8 Dobrá Voda - a village in western Slovakia, where the Catholic priest Ján Hollý spent the last years of his life. He died there in 1849 and is buried in the local cemetery.

9 Andrej Kováčik, an academic painter who began to devote himself to painting historical scenes in the inter-war period. His most important work is precisely his picture from 1935 of the Visit of Štúr, Hurban and Hodža to Ján Hollý at Dobrá Voda in July 1843. This work by Kováčik is part of the presentation of the symbolic aspect of the codification of written Slovak. 
the Trnava dialect ${ }^{10}$ and present to him the arguments for using the pure central Slovak dialect. ${ }^{11}$ The master of the house Dean Lackovic ${ }^{12}$ hospitably received us and from the old bard, a tall distinguished figure with large light eyes and silver hair, a welcome with kisses and tears of joy. He not only had nothing against pure Slovak, but actually stated that in his time it was not possible to write books in Slovakia in a form of Slovak different from that used by his late friend Bernolák in his grammar book. ,And" he said "my metre can be excellently used in this speech. Folk songs sound most beautiful in upper Slovak speech." ${ }^{\prime 3}$ This was Holly's view, with which we understandably entirely agreed. Holly' gave his blessing to the work we planned." 14

As members of the Protestant community, Štur and his followers were originally strongly influenced by the ideas of Ján Kollár and preferred to communicate in the Czech language, ${ }^{15}$ but from the middle of the 1830 s, they ever more intensively followed J. Hollý: "The deep humanity and democracy of Holly's work and especially his unwavering faith in the future of his nation influenced the young, nationally conscious generation. Holly's personality and character traits - dignity, firmness, hard work and modesty - were not the least important factor. The romantics saw these traits as characteristic of their nation. "16

10 The Trnava dialect or western Slovak dialect or inter-dialect influenced by the cultured environment of Trnava University in the $18^{\text {th }}$ century and codified by Bernolák. J. Hollý was the last important poet to write his works of literature in this form of Slovak.

11 The Romantics saw Central Slovak as the representative and most widespread form of the language.

12 The Catholic priest Martin Lackovič, a friend and former pupil of J. Hollý, placed him at Dobrá Voda, after the village of Madunice including Hollýs home, the house of its Catholic priest, was afflicted by a great fire in May 1843.

13 Upper Slovak speech - J. M. Hurban passed on in this quotation Hollýs reflection on the language or dialect situation in Slovakia. It was an archaic variant no longer used today either in expert literature or in ordinary communication. It does not divide the Slovak language area along the west - east geographical axis, into West Slovak, Central Slovak and East Slovak dialects, but on the north - south axis into Upper Slovak and Lower Slovak dialects.

14 HURBAN, Jozef Miloslav. Ludovit Štúr. Rozpomienky. (Ludovit Štúr. Memories). Ed. Zuzana Šeršeňová. Bratislava: Vydavatel'stvo SLOVART, spol. s r. o. in cooperation with the TASR, p. 336, 337. ISBN 9788055614236.

15 Czech as the liturgical language of the Slovak Evangelicals in the Kingdom of Hungary was originally associated with the language of the Kralice Bible. In the course of its historical development it became Slovakized in the Slovak environment, but in the first half of the 19th century it no longer satisfied the criteria that began to be applied to a modern language of public communication.

16 FORDINÁLOVÁ, Eva. L’udovít Štúr a Ján Hollý. In SEDLÁK, Imrich (ed.). Ludovit Štúr $v$ súradniciach minulosti a súčasnosti. Zbornik z medzinárodnej vedeckej konferencie $v$ dñoch 10. - 11. januára 1996 v Modre-Harmónii v rámci celonárodných podujati Roka Ludovita Štúra. Martin: Vydavatel'stvo Matice slovenskej, 1997, p. 68. ISBN 8070904046. Among the 
It is necessary to mention that the young romantics accepted especially the conceptual message of J. Holly's literary works, which brought them a picture of the glorious past of the Slovaks, with Great Moravia as a Slovak nation state, ${ }^{17}$ but they rejected its linguistic aspect, namely use of the West Slovak form of the language as codified by A. Bernolák.

The first attempts to establish contact and cooperation with Hollý happened in 1835. They were probably connected with the fact that in the school year 1835-1836 L. Štúr became the deputy chairman of the student Czecho - Slovak Society at the Evangelical Lyceum in Prešporok (now Bratislava). According to Eva Fordinálová, Štúr himself was "one of the first individuals to establish [...] personal contacts with Hollý. [...] He began to show great respect for Holly and probably made the greatest contribution to creating the Holly' cult among members of the Society in the following years". ${ }^{18}$

The respect of Štur's group for Hollý was accompanied by a gradually strengthening Slovakizing tendency, which eventually led to these young members of the Lutheran intelligentsia deciding to abandon Czech and adopt Slovak as their written language. As stated in the book accompanying the new exhibition of the Ludovít Štúr Museum at Modra, "thanks to this decision, Štúr's strand of the national movement moved closer to the young Catholic followers of Bernolák, ${ }^{19}$ blunted their differences of view and overcame the basic obstacle to achieving national unity, which Štúr raised above confessional, social, regional and linguistic traditions. A clear majority of the national movement agreed with Štur's conception. They opened the doors to new forms of cooperation and it became possible to clarify the basic questions of further progress much more quickly. The national movement penetrated more substantially into Slovak society and acquired a political dimension". ${ }^{20}$

followers of Štúr the Hollý cult replaced the older cult of Ján Kollár. Around 1840 the young students at the Bratislava Evangelical Lyceum still venerated Kollár "like an idol". ŠKVARNA, Dušan. Začiatky moderných slovenských symbolov. K vytváraniu národnej identity od konca 18. do polovice 19. storočia. (The beginnings of modern Slovak symbols. On the creation of national identity from the end of the 18th to the middle of the 19th century). Banská Bystrica: Univerzita Matej Bela v Banskej Bystrici, 2004, p. 59. ISBN 8080550142.

17 The Great Moravian period associated with the mission of Cyril and Methodius was seen by Enlightenment and Romantic intellectuals as a "golden" age in the history of the Slovaks

18 FORDINÁLOVÁ, ref. 16, p. 61.

19 The young followers of Bernolák - mladobernolákovci in Slovak - were younger members of the Catholic intelligentsia, mostly students of theology, who originally supported Bernolák's codification, but eventually became inclined to L. Štúr's language reform.

20 ŠKVARNA, Dušan - MIHALKOVIČOVÁ, Beata. Ludovit Štúr a moderné Slovensko. Stála expozícia SNM - Múzea Ludovíta Štúra. (Ludovit Štúr and modern Slovakia. Permanent exhibition of the SNM - Ludovit Štúr Museum). Modra: SNM - Múzeum L'údovíta Štúra, 2015, p. 99-100. ISBN 9788080603700. 
There is no doubt that from the narrowly expert point of view, the process of the formation of standard written Slovak was a longer term and relatively complex process. However, if we look at this process through the lens of the national ideology and politics of national memory, if we want to investigate the media and mechanisms of nationalization of the widest groups in society, it is necessary to ask the question of why did precisely the meeting of L'. Štúr, J. M. Hurban and M. M. Hodža at Hlboké and the subsequent visit to J. Hollý at Dobrá Voda became one of the key elements in the Slovak national narrative. Why did some other historical episode not achieve this position? Other events and stories also come into account.

These include not only 10 August 1847, namely the fourth general assembly of the Tatrín Society at Čachtice, ${ }^{21}$ at which representatives of the national movement from the ranks of the Catholic and Protestant intelligentsia officially and definitively decided that Štúr's version of Slovak would be the standard written language. ${ }^{22}$

Another alternative offered by history is 21 October 1851, when a meeting in Bratislava considered the reform of Slovak orthography. Representatives of the Evangelical: L. Štúr, J. M. Hurban, M. M. Hodža, and of the Catholic intelligentsia: Andrej Radlinský, Ján Palárik, Štefan Zavodník and Martin Hattala, participated. They agreed to apply not the purely phonetic principle in standard Slovak spelling, but the historical - etymological principle. Among other things, this meant the introduction of the letter "y" (ypsilon) to the Slovak language.

Historic events connected with the publication of the linguistic writings of L. Štúr or M. Hattala, which represented the culmination of the process of codification or important milestones in it, can also be considered relevant in this context. However, in comparison with the above mentioned historical episodes, their potential usability for the needs of the national ideology or for shaping the collective memory and identity of the Slovaks was much less. No specific,

21 Some sources state that the new form of the Slovak language was already accepted in the framework of Tatrín in 1844. See, e.g. KAČALA, Ján - KRAJČOVIČ, Rudolf. Prehl'ad dejín spisovnej slovenciny. (A review of the history of standard written Slovak). Martin: Matica slovenská, 2006, p. 80. ISBN 8070908130 ("The codification of Štúr's standard written Slovak was officially approved at a session of Tatrín in Liptovský Mikuláš in August 1844 "). In reality, however, the new standard written language was approved only by members of the Protestant intelligentsia. In this context J. Demmel stresses that up to 1847 Tatrín was an almost exclusively Evangelical society from the point of view of confessional composition. DEMMEL, József. L'udovít Štúr. Zrod moderného slovenského národa v 19. storočí. (L'udovít Šturr. The birth of the modern Slovak nation in the 19th century). Bratislava: Kalligram, 2015, p. 199. ISBN 9788081018794

22 I will mention that varying views on the exact form of the orthographic system did not cast doubt on the essence of the decision to use a standard written language based on the Central Slovak dialect. 
clearly instrumentalizable and memorable micro-story, which would help to shape the collective emotions, mental disposition and social ideas of the people of Slovakia, was connected with them.

I observe that when mentioning these alternatives, I deliberately omitted one of the milestones in the journey of Štúr's group towards their new standard written Slovak. On 14 February 1843 a small group of Štúr's followers went for a walk in the country near Modra and decided to abandon Czech and introduce Slovak as their written language. It happened between 15.00 and 17.00. The participants in this conspiratorial walk were L'udovít Štúr, Ján Francisci, Ján Kalinčiak, Samo Vozár, Ján Gáber Lovinský and Samuel Štúr junior.

In his lecture given in December 1943 to the Štur Evangelical Society on the occasion of the centenary of the standard written language, the historian Daniel Rapant ${ }^{23}$ designated precisely this date and so this historic event as the moment of the resurrection of the new standard written Slovak. The decision of Štúr's group was influenced especially by two important circumstances: Firstly, the publication of a royal resolution prohibiting Illyrianism in January $1843,{ }^{24}$ which Rapant saw as a definitive breaking point for the Czechoslovak conception of Štúr's group as they very quickly realized. Secondly, their decision to switch from Czech to Slovak was influenced by the part of the lower nobility of Upper Hungary, especially the County of Turiec, which demanded the publication of newspapers in Slovak..$^{25}$

Although the precise dating or timing or this meeting is almost fascinating, the paradox remains that it remained unknown to the Slovak public for a long time. It is not mentioned by Hurban in his biography of Štúr. We learn of it only from a letter, which L. Štúr addressed to Samo Bohdan Hroboň in September $1844 .{ }^{26}$

23 RAPANT, Daniel. Nastolenie spisovnej slovenčiny. (The establishment of standard written Slovak). In Služba, 1944, year 8, no. 1-2, p. 16-28.

24 For more details see BEDNÁROVÁ, Marcela. Symboly a mýty chorvátskeho národného hnutia. Fenomén ilyrizmu. (Symbols and myths of the Croatian national movement. The phenomenon of Illyrianism). Bratislava: VEDA, 2012, p. 45. ISBN 9788022412537.

25 The most recent statement on this problem is DEMMEL, József. Spisovná slovenčina a uhorsko-slovenské zemianstvo. Štúrovčina ako nástroj spoločenskej integrácie? (Standard written Slovak and the Hungarian-Slovak lesser nobility. Štúr's standardized language as an instrument of social integration?). In MACHO, Peter - KODAJOVÁ, Daniela a kol. Ludovit Štúr na hranici dvoch vekov. Život, dielo, doba verzus historická pamät'. Bratislava: Historický ústav SAV vo VEDE, vydavatel'stve SAV, 2015, p. 53-68. ISBN 9788022414548. The author's argumentation agrees in principle with D. Rapant's interpretation. J. Demmel (p. 56) states that Štúr's group reached their decision only a few days after Štúr received from Juraj/ Gyorgy Kossuth (uncle of Lajos Kossuth) a petition from the lesser nobility of Turiec in support of the publication of a newspaper in Slovak.

26 AMBRUŠ, Jozef (ed.). Listy Ludovita Štúra II. 1844 - 1855. (Letters of Ludovit Štúr II. 1844- 
It is possible to definitely state that up to the middle of the 20th century when expert historiography mentioned and thematized this historical event, the date 14 February 1843 did not figure in public discourse, so it could not "compete" on the symbolic level with another date, another historical micro-story about the birth of standard written Slovak, which had been established already in the course of the 19th century.

Let us recapitulate the identity-forming potential of this historic event or the narrative of this event: It was a private, informal meeting resulting from an internal decision by a small group composed of Štur and associates from the Lutheran community. Although we can suppose that ideas about cooperation with the Catholic young followers of Bernolák were heard at the meeting, members of the Catholic intelligentsia were not participants. Catholics clearly do not figure in this historical micro-story as direct actors, so its instrumentalization and media promotion cannot make it a legitimizing instrument for the process of inter-confessional cooperation and the creation of potential national unity. Moreover, as I already indicated, this historical event was not known for a long time, and essentially Rapant's reference to it in December 1943 shows that for him it was more an expert than an ideological matter, ${ }^{27}$ in spite of the fact that he used the pseudo-religious term resurrection of Slovak, evidently taken over from the vocabulary of the romantic nationalists of the period.

The situation is similar with the July meeting of Štúr's group at Hlboké: The micro-story about how L. Štúr, J. M. Hurban and M. M. Hodža met in Hurban's parsonage at a small village in the Záhorie district, and agreed on the introduction of the new written language is most frequently mentioned as a symbolic act in the codification process.

I will state that mentions of the enactment (uzákonenie) of standard written Slovak still occur in this context today, ${ }^{28}$ although the tendency to replace the

1855). Bratislava: Vydavatel'stvo Slovenskej akadémie vied, 1956, p. 58-59, 353, letter 195.

27 This statement needs to be seen against the background of the political-ideological situation: the celebration at which Rapant's lecture was heard, was organized after the Štúr Evangelical Society refused to participate in pro-regime celebrations of the centenary of standard written Slovak. Slovenská národná knižnica (Slovak National Library) Martin - Literárny archív (Literary Archive), fond (collection) Samuel Štefan Osuský, signatúra 46 BBB 1, Štúrova evanjelická spoločnost' - zápisnice. (Štúr Evangelical Society - minutes). Committee meeting of the Štúr Evangelical Society in Bratislava, held on 18 February 1943 [...].

28 See, for example, Dokumenty slovenskej národnej identity a štátnosti I. (Documents of Slovak national identity and statehood I.). Bratislava: Národné literárne centrum, 1998, p. 299 (document 99, Uzákonenie spisovnej slovenčiny (Enactment of standard written Slovak.).). ISBN 8088878438; similarly FRANKOVÁ, Libuša. Slováci v novom veku národov (17801848). (The Slovaks in the new age of nations). Prešov: Universum, 2006, p. 113. ISBN 8089046398. The author uses the words codification and enactment as synonyms, as these words essentially are. In my view the primary meaning of the term codification as a word of 
expression enactment with the term codification has strengthened in expert circles in recent decades. The problem does not lie only in the fact that the word enactment unintentionally suggests the idea of a sort of public legislative act. The meeting at Hlboké in July 1843 and the decision made there cannot be described as such an act. It is similar in the case of 14 February 1843 - a conspiratorial meeting of L. Štúr and a small group of his followers, and now it was more or less a matter of a private meeting of a few members of Štúr's group, again all members of the Evangelical - Lutheran community, but this time not only students, but adult men, already established in the national movement.

Hurban's biographer Tomáš Winkler describes the atmosphere at Hlboké rather similarly, bringing especially to the uninformed reader the surprising information that Šturr, Hurban and Hodža were not the only participants in this meeting and that agreement on the Slovak language was not reached: "A friendly atmosphere prevails at the Hlboké parsonage, but it cannot cover up the difference of views. On one side are Štúr with Hurban - enthusiastic supporters of the decisive step [away from Czech] and towards Slovak - and the hesitant Hodža encouraging caution, with on the other side Kadavy, ${ }^{29}$ who warns them against the dangerous consequences of the linguistic split."

Winkler continues his narrative, which disturbs our idyllic or rather simplified, reduced picture of what happened at Hlboké: "In the fine summer week from 11 to 16 July 1843, agreement of views does not prevail in the parsonage at Hlboké. The great barrier on the road to Slovak is precisely Hodža. [...] The most trustworthy person - Samo Bohdan Hrobon - knows about his negative attitude to the Slovak language several weeks after the Hlboké meeting [...]. This had to remain covered up and unknown to everybody, as Hurban informed a not very curious Slovakia. [...] In the end they agree to wait a year concerning the development of the Slovak language question, but essentially they are only waiting for Hodža's agreement. A whole long year with life going on and bringing many changes. Štur and Hurban had certainly hoped that the Hlboké meeting would end with agreement and they would find one channel along which Slovak life would flow. But instead of agreement, dispute arose and the urgent problem of the Slovak language was postponed. To ensure that they are proceeding correct-

foreign origin appears to be more appropriate, because it does not appear to evoke a connection with the legal sphere, although that is its actual origin.

29 Ján Kadavý, a member of the Czech intelligentsia working in the Slovak environment, was a teacher at the Evangelical church school in Pest at the time of the Hlboké meeting. At first he belonged to the supporters of Ján Kollár, but later came into conflict with him because he inclined to the Slovak language.

30 WINKLER, Tomáš. Perom a mečom. Biografia J. M. Hurbana. (With pen and sword. A biography of J. M. Hurban). Bratislava: Tatran, 1982, p. 53. 
ly, they visit Holly' at Dobrá Voda and discuss everything with him. Holly' agrees with the progression to the Slovak language. "'31

In essence therefore, Hlboké $1843^{32}$ did not bring unambiguous agreement or a decision with which all participants in the meeting could agree, it was not sufficiently transparent and was still one-coloured from the confessional point of view, although as we have seen from the concluding sentences of Winkler's text, the actors in this historic event undertook a symbolic gesture, which to some extent compensated for this shortcoming: They visited the important Slovak poet and Catholic priest Ján Hollý at Dobrá Voda.

From the point of view of the above mentioned criteria, we should more positively evaluate the general assembly of the Tatrín Society in the western Slovak village of Čachtice, which officially approved or declared Štúr's version of Slovak to be the official written language in August 1847. It not only had a transparent character, but also a significant institutional background. It provided not only the authority of specific, widely recognized individuals, but also the authority of a national society that backed the decision taken by members of both the Catholic and Evangelical intelligentsias.

A further historical event, a post revolutionary meeting of a narrower circle of Catholic and Evangelical patriots or nationalists in October 1851 in Prešporok (Bratislava), fulfils the criterion of cooperation and consensus between the confessions, but in comparison with the above mentioned general assembly of Tatrin in Čachtice, it was a rather less transparent event. The achievement of agreement on the linguistic question in this case gives the impression of a product of rational - pragmatic effort by the participants. The Bratislava meeting does not look like a meeting of engaged patriots, but more a session of a bureaucratized language commission from the second half of the 20th century, held behind closed doors and without the presence of emotions. It is also necessary to realize that in October 1851 the position of Central Slovak as the standard written language was no longer a problem. They were not solving basic, so to speak, existential problems, only specific questions of spelling.

If we consider the individual events or the associated micro-narratives from the emotional point of view, we very quickly find that, for example, Hurban's biography of Štúr from the 1880 s describes the visit to Dobrá Voda rather similarly and with a definite emotional charge. In his memoirs he has Hollý directly

31 WINKLER, ref. 30, p. 54.

32 In the following parts of this study, I will use abbreviated and schematized designations for the individual historical events or episodes connected with the process of formation of standard written Slovak and with specific dates as follows: Bratislava 1843 (14 Feb 1843), Hlboké 1843 (11 - 16 July 1843), Dobrá Voda 1843 (17 July 1843), Čachtice 1847 (10 Aug 1847), Bratislava 1851 (21 Oct 1851). 
speaking of the merit of the issue of the Slovak language. However, in the preceding passage of this text, describing the meeting at Hlboké, we look in vain for any emotion in the account of the arguments about the Slovak language within the walls of the Evangelical parsonage. Hurban is tactically silent, mentioning only the intention to establish the Tatrín society.

Undoubtedly, the other historical events mentioned here must have been accompanied by strong individual emotions, whether negative or positive. This is entirely natural considering the participation of people with such character traits as those of Hurban, but expressions of these emotions were left out of the historical narratives. They did not penetrate into the collective memory as part of the particular micro-stories. Moreover, as we see, Hurban himself deliberately left them out of his text. He probably did this to produce a picture of a harmonious atmosphere and unity of view at the Hlboké meeting. He strove to downplay the real disputes between Štúr and Hurban on one side and Hodža with Kadavý on the other. From his position in the 1880s, when he wrote his biography of Štur, not only as a person who remembered, but also as a national ideologue, who passed on social models and national symbols to the public, it was logical: In his account, Hollý did not need to play the role of a sort of arbitrator or mediator between divided followers of Štúr. Hurban wanted to use the Dobrá Voda 1843 micro-narrative, which directly continued the events in the Hlboké parsonage, to legitimate Štúr's linguistic and national conception by supporting it with Hollý's authority.

Although Hurban mentions the trip to Dobrá Voda, ${ }^{33}$ at another point in his text, he writes of visits to Hollý, including earlier ones, by the patriots as pilgrimages: "We went on pilgrimages to Madunice, where Ján Holly', the distinguished and enthusiastic Slovak poet held the post of Roman Catholic parish priest." ${ }^{34}$

Thus, the visit to Dobrá Voda on 17 July 1843, about two months after the fire at Madunice was a sort of pilgrimage. The meeting with the greatest Slovak poet, but at the given moment also the greatest Slovak martyr, Hollý who had escaped only with his life, and, so to speak, been born again, is caught by Hurban's pen in a rather idyllic form: He does not mention the poet's human and physical suffering ${ }^{35}$ on the contrary, contentment, optimism and joyful welcoming by the great

33 HURBAN, ref. 14, p. 336, similarly on p. 59.

34 HURBAN, ref. 14, p. 55.

35 The testimony of Ján Francisci, who, together with S. Vozár and J. Gáber Lovinský, visited Hollý at Madunice immediately after the fire in May 1843, is entirely naturally more specific from this point of view: He mentions not only the destroyed church and priest's house, but also Hollý's burns and his poor food (millet mash in a trough): "Everything we saw and the appearance of Holly' made such an impression on us that we almost fell on our knees before 
poet of Štúr and his associates radiate from the account. The basic outline of the micro-story of Dobrá Voda 1843 distantly resembles the Biblical pilgrimage of the three wise men from the East: Štúr, Hurban and Hodža come to pay homage to the national bard and bring him a really special spiritual gift: news of their decision to adopt a new standard written language.

\section{$* * *$}

The literary historian Eva Fordinálová comments on the difference between the historical reality and Hurban's account, that 'although we know from Holly's correspondence with Martin Hamuljak ${ }^{36}$ that he did not express direct agreement [with the introduction of the new standard written language - note P. M.], the decisive thing was that he did not take up a position of unambiguous opposition. On the contrary, at the end of the visit, he gave J. M. Hurban, L. Štúr and M. M. Hodža his priestly blessing, which the codifiers regarded as approval. ${ }^{\prime 37}$

In this context, the researcher also points to other aspects: "In this [...][Hurban's] account of the Dobrá Voda atmosphere [published in the 1880s in the framework of a biography of L. Štúr] a moderate hyperbolization is felt under the influence of time and later political events, but no mystification. Holly's psychic support was 'living water'for them in the struggle for the Slovak language in later years. The blessing they received from him was clearly more the act of a priest than of a national representative, but Šturr, Hurban and Hodža returned from this visit unambiguously 'encouraged in the national faith'. "'38

Therefore, the author states that from Hurban's side it was a matter of exaggeration, but not of deception or fraud. Essentially, she reacts to the voices, appearing sporadically in popularized accounts, alleging that in his biography of Štúr, Hurban deceived the Slovak public, when he gave the impression that Hollý had expressed his support for the introduction of the new standard written language based on the Central Slovak dialect.

him and we hardly knew what to say." Cited according to AMBRUŠ, Jozef (ed.). Ján Hollý očami svojich súčasnikov. (Ján Hollý through the eyes of his contemporaries). Bratislava: Slovenské vydavatel'stvo krásnej literatúry, 1964, p. 184.

36 Martin Hamuljak - a member of the Catholic intelligentsia and high state official. In national cultural activities he promoted cooperation between Catholics and Evangelicals. He was an important supporter and organizer of the literary and society life of the Slovaks.

37 FORDINÁLOVÁ, Eva. Dozrievanie Hurbanovej osobnosti a zápas za slovenčinu. (The personal maturing of Hurban and the struggle for the Slovak language). In ROLKOVÁ, Natália (ed.). Jozef Miloslav Hurban - prvý predseda Slovenskej národnej rady (Príspevky k 190. výročiu narodenia). Bratislava: Kancelária Národnej rady Slovenskej republiky, 2007, p. 54, 55. ISBN 9788089052370.

FORDINÁLOVÁ, ref. 37, p. 55. 
If we admit that J. Hollý did not express a clear view on the problem of the standard written language when Štúr and his two associates visited him in the priest's house at Dobrá Voda, and that J. M. Hurban was aware of the ambiguous position of this important personality in the national cultural life of the Slovaks, then it is logical that in his interpretation of the visit to Dobrá Voda he strove to compensate for this ambiguity by presenting the above mentioned act of blessing as something not intended only for the three visitors: Štúr, Hurban and Hodža, but indirectly for the whole of Slovakia. In Hurban's understanding, it is more a message from an important authority addressed to all the Slovaks.

On the other hand, the ambiguity of Holly's position is disturbed in Hurban's text by an approach that we could understand as a specific rhetorical strategy. Hurban does not write that Hollý explicitly stated his support for the new standard written Slovak, that he directly approved it. He "only" convinced his readers that Hollý "had nothing against pure Slovak", which indirectly indicates that Hollý essentially agreed with Štúr's linguistic conception. At the same time, however, he is silent about the poet's individual decision to continue using Bernolák's version of Slovak. He does not mention it, and essentially we do not know whether Hollý directly expressed his decision during the meeting. ${ }^{39}$

Therefore, Hurban does not express Hollýs alleged agreement by means of direct speech, he does not put a concrete statement into Hollýs mouth, but uses only the accompanying author's commentary, which is a really "Solomonic" solution to this problem. By means of a double negative, he formulates Holly's position as a negation of a negation ("nič nemal proti čistej slovenčine" - "he did not have anything against pure Slovak"). If we compare this method of expressing agreement with the potentially different but in ordinary human communication more usual way of expressing agreement ("to have nothing against..." rather than "to agree with..."), we will notice the fine nuances distinguishing these two formulations. In the end, this lies behind Hurban's statement: On the one hand, he gives the reader the impression that Hollý agreed with Štúr's conception, but, at the same time, he uses "flexible" language to indicate to the reader that this agreement shows a clear lack of personal or emotional enthu-

39 On the margin of this moment, another researcher has commented: "Above all, perhaps a not entirely exact interpretation has been passed down [...] of how Holly' 'sanctified' [...] the decision [of Śtúr's group] to introduce a new form of standard written Slovak, and that he would remain faithful to Bernolák's version only from inertia. [However,] Karol Rosenbaum [...] emphasizes that it was not entirely so, but that Hollý did not give up Bernolák's version of Slovak from his own conviction, in spite of the fact that as an 'aging poet he must have been aware that the more creative forces were no longer in Bernolák's camp [...]'.” RIŠKOVÁ, Lenka. Z korešpondencie Jána Hollého. Niečo o vzt’ahu Jána Hollého k protestantským autorom. (From the correspondence of Ján Hollý. On Ján Hollýs relations with Protestant suthors.). In Slovenská literatúra, 2015, year 62, no. 6, p. 496. ISSN 0037-6973. 
siasm from Hollý. These facts lead to the conclusion that Hurban's testimony on the poet's support for the introduction of the new standard written language has an essentially ambivalent character, but in reality Hurban directly disturbs this ambivalence, when he lets Hollý speak and puts in his mouth the sentence: "The folk songs sound most beautiful in the Upper Slovak speech." It is an idea or argument that is more typical for the romantic generation, stressing not only the idea of the purity and melodious nature of the Central Slovak dialect or specifically its Liptov variant, but also the idea of folklore as the basic inspiration for the shaping of national culture, replacing the antique or classical models originally preferred precisely by Hollý. It is questionable whether Hollý really expressed this idea, if it was anchored in different mental structures and a different cultural context, or whether he understood it in harmony with romantic ideals. However, Hurban's testimony was pursuing an important aim, namely to prove that Hollý's views corresponded to the ideas and aims of Štúr's generation. Therefore, Hurban evoked the image of Hollý as a person who realized his place in the cultural historical development of Slovakia and his place in time, so that he positively reflects and accepts the coming of a new generation, solving similar problems, but with different instruments and resources, namely the replacement of Western Slovak with Central Slovak.

Using language on the lexical and stylistic level, Hurban constructs a particular form of historical fact. However, retelling Štúr's life-story, and in this context also describing the events at Hlboké and Dobrá Voda, was accompanied by a deliberate selection and retouching of the facts. It seems that Hurban deliberately gave some moments in this micro-story a different weight or different meaning to that probable in historical reality. Hurban's account is essentially tangled, and it is relatively difficult to distinguish the author's story-telling, pure fiction or only shifts of significance compared to the historical truth produced for national ideological reasons. However, other factors come into play, especially human psychology, a phenomenon usually not considered very much by historians.

We can illustrate this fact using the case of the second component of the story told by Hurban, namely the blessing that Hollý granted to Štúr and his friends. As we already stated above, E. Fordinálová that it was more the act of a priest, a traditionally understood religious act, which Štúr's group interpreted and later presented as a national blessing, a blessing of their national cultural activity. According to Hurban: "Holly granted us his blessing of our then modest works" referring to the codification of the language and the establishment of the Tatrin society. Is this an ideologically motivated shift of meaning compared to the historical truth? Or to put it more firmly, is it a direct falsehood or untruth?

In this context, I think it is relevant to mention the statement of a psychologist of communication, who emphasized that "the essence of receiving and decoding 
communication is the assignment of the meaning of a message and not only its content to the mental structures of the recipient". Moreover, receiving a message or any information is not a passive, but an active process: "There where we strive to understand, to listen in a very concentrated way, although we want to receive checked communication, even conscious checking and immediate verification of the received content is no guarantee of 'objectivity'. In this sense, the phrase 'objectively inform' sometimes in opposition to subjective news, is more cliché. Objective communication is fiction and objective information is the same illusion." $" 40$

The literary historian Jana Pácalová, who analysed Hurban's biography of Štúr very thoroughly, states that Hurban's motivation to re-tell or describe events in a different way to the reality was an "installation of the truth" that he as the author "perceives and then textually constructs, depicts and in this way confirms and strengthens as the objective, historical truth". ${ }^{41}$

However, if we direct our attention to the above mentioned act of blessing, we must ask the basic question: Did Hurban really describe the event differently to what really happened, or did he really attribute the act of blessing a meaning in conflict with Holly's intention? The problem lies in the fact that we really do not know the objective reality at all. We do not know the intention of Hollý's act of blessing, not only because we lack a source not formulated retrospectively, which would unambiguously and without doubt define this act from Hollý's point of view, but also because apart from Hurban's testimony we do not have any sources that shed light on this problem from the point of view of any other participants in the meeting at Dobrá Voda.

In this context, I will mention the fact that a letter J. Hollý addressed to Martin Hamuljak on 23 August 1844, about a year after the view of Štúr and his two friends to Dobrá Voda, is traditionally considered by researchers to be a relevant source explaining the views and motivations of J. Hollý. He reacted in this letter to the publication of the second annual publication of the almanach Nitra, the first book in Štúr's version of Slovak. He stated that the "Lutherans" were keeping their promise to change from Czech to Slovak and had really begun to write in Slovak. However, he was dissatisfied with the fact that there would be two forms of standard written language used in Slovakia: Štúr's "Upper Slovak" and

40 VYBÍRAL, Zdeněk. Psychologie komunikace. (The psychology of communication). Praha: Portál, 2009, p. 55. ISBN 9788073673871.

41 PÁCALOVÁ, Jana. Subjekt, pamät' a identita v literárnych portrétoch Ludovíta Štúra. (Subject, memory and identity in the literary portraits of L'udovít Štúr). In MACHO, Peter - KODAJOVÁ, Daniela et al. Ludovít Štúr na hranici dvoch vekov. Život, dielo, doba verzus historická pamät'. Bratislava: Historický ústav SAV vo VEDE, vydavatel'stve SAV, 2015, p. 140. ISBN 9788022414548. 
Bernolák's "Lower Slovak". He immediately emphasized his position: "However, if I could I would have the Lower Slovak used among Catholic Slovaks and most advantageous for all used permanently. But I cannot, blindness is the greatest obstacle for me." ${ }^{42}$ The cited sentence clearly shows that in August 1844 Hollý did not approve Štúr's codification based on Central Slovak and wanted to keep the Western Slovak codified by Bernolák, because in his view it was tried and tested. He regarded it as the most advantageous for creating a standard written language. He wanted to remain faithful to it, but he stressed that in real, practical terms it was no longer possible for him, because he had almost lost his sight as a result of the fire at Madunice. It is logical to suppose that the poet had held this view of Šturr's linguistic project continually, including at the time of the meeting in the priest's house at Dobrá Voda in July 1843.

J. Hollý expressed a similar position in a letter addressed to Hamuljak on 20 July 1846. He states that Štur and his associates had visited him and tried to persuade him to encourage the circles of Catholic intellectuals to support the idea of meetings between adherents of Štúr's and Bernolák's versions of Slovak so that they could have discussions and reach agreement and unity on the language question. ${ }^{43}$ Hollý essentially rejected the role he was offered as mediator, giving his poor eyesight as the excuse. However, the real reason for his reluctance or unwillingness was his clear disappointment over the fact that Štúr's group did not accept Bernolák's Western Slovak as the standard written language: "If they had remained with our version of Slovak there would have been no problem." 44

The problem of the two cited letters as relevant sources concerning the granting of a blessing to Štúr, Hurban and Hodža in 1843 lies in the fact that they were written only a considerable time - one to three years - after the visit to Dobrá Voda, and Hollý does not directly mention the blessing in either of them. Understandably, the information obtained from these two sources, namely that Hollý emphasized "faithfulness" to Bernolák's Western Slovak, has such a character that a researcher can logically deduce a conclusion casting doubt on Hurban's interpretation of the act of blessing. In the end, simple common sense also demands the question: Why would Hollý grant his blessing to Štúr and his two friends and so legitimize national activities with which he did not personally identify? One of the possible explanations is that at the given moment in July 1843, he was still inclined to believe that Štúr's group would change their view of Bernolák's version of Slovak. It is clearly possible to object to the speculative

42 AMBRUŠ, Jozef. Korešpondencia Jána Hollého. (Correspondence of Ján Hollý). Martin: Matica slovenská, 1967, p. 183, letter 94.

43 Eventually such a meeting was held a year later in 1847 in Čachtice at the fourth general assembly of the Tatrín society.

44 AMBRUŠ, ref. 42, p. 195-197, letter 104. 
nature of this method of argumentation, since the sources give no clear evidence that Hollý was pursuing such tactics.

The verbal act of agreement and ritualized act of blessing represented "connected vessels" in Hurban's text. Hurban understood and presented them as corresponding and connected micro-events or phenomena, which we could describe more as symbolic gestures. However, Hollý himself also had such an understanding of them, although probably with a different approach to evaluation or a different communicative intention. As we see, ambiguity of approval was associated with ambiguity of the blessing. However, this statement leads to an insoluble puzzle. To avoid misunderstanding, I will observe that I do not want to prove which decoding of Hollý's symbolic gesture, namely his blessing, is "correct" religious or national? On the contrary, I want to prove that it cannot be proved: We will probably never be able to untie or cut through this little Gordian knot. We will always remain on the level of guesses. Essentially also E. Fordinálová's formulation: "The blessing [Štúr's group] received was clearly more the act of a priest than of a national representative [...]." implies an important reality: The author is aware that the available sources do not enable us to state whether Hollý was performing a traditionally understood religions act, or whether he himself attributed some degree of a national dimension to it.

Thus, if we confront the value as evidence of the appropriate accessible sources with the findings of the psychology of communication and place them in the context of Hurban's version of the micro-narrative Dobrá Voda 1843, we researchers must admit the fact that we cannot objectively judge whether J.M. Hurban deliberately and with ideological motivation, misinterpreted Hollý's blessing, and so used untruth or deception in the service of the national idea. However, I point to the fact the nationalist decoding and subsequent presentation of the act of blessing as we know it from Hurban's biography of L. Štúr, entirely corresponds to the pseudo-religious structure of the symbolic representation of Hollý as the Father of the Slovaks. This is seen, for example, in the frequently cited letter from June 1843, which the students of Bratislava addressed to the poet on the occasion of his name day. ${ }^{45}$

I point here to the view of Hollý in Štúr's circle, or to his dual significance: either as the Reverend Father, namely the traditional address for a priest in the Catholic environment, clearly used here with respect by the Evangelical students, or as the Father of the Slovaks, a designation constructed against the background of a religiously structured culture and adapted to the rhetoric of

45 Congratulations to Hollý, see, for example in the publication: FORDINÁLOVÁ, Eva. Otec a syn národa. Vzt'ah Jána Hollého a Ludovita Śtúra. (Father and son of the nation. Relations between Ján Hollý and L’udovít Štúr). Skalica: Záhorské múzeum v Skalici, 2015, p. 69, 70, 71. ISBN 9788085446838. 
nationalism. Precisely the understanding of Hollý as the Father of the Slovaks indicates that the thinking of Štur's group was mainly nationalist. From the point of view of this mentality, it was entirely logical that Hurban interpreted Holly's act of blessing in national terms. It would be rather strange, and would evoke many more questions from recent researchers, if Hurban, as a member of a patriotic essentially nationalist community, which regarded Hollý as an important symbol of Slovak nationalism, had interpreted and then presented this gesture in non-national terms.

Jana Pácalová states that "the method of relating to a collective identity by means of construction of personal testimony as in [...] Hurban's [...][biography of Ludovít Štúr], is typical of memoir texts from this period. Hurban's biography is an apparently exemplary case because it is an extremely well known text, which established itself in competition with other testimonies of the period than$k s$ to the fact that it was accepted as the text institutionalizing the collective memory of L'udovit Štúr", ${ }^{46}$

We can clearly widen or modify the author's description of this biography in the sense that it is a text that also institutionalized the collective memory of 17 July 1843, or, in other words, of Dobrá Voda 1843.

Essentially, the visit of Štúr's group to Dobrá Voda - as Hurban presented it to the public - was a symbolic act. It was accompanied by emotions built up against the background of the relations of Štúr and his group with Hollý, which are presented in filial - paternal terms. However, these characteristics, which the historic events such as Čachtice 1847 or Bratislava 1851, and the associated micro-narratives mostly lack, are immensely important for the shaping of collective memory and identity. The micro-story of the visit to Dobrá Voda and within it Hollýs publicized but only alleged agreement or blessing acquired a legitimizing function among the symbolic instruments: The story and within it especially the image of Hollý symbolically sanctified Štúr's linguistic conception. In the context of the struggle over standard written Slovak in the 1840s, it functioned as a legitimizing instrument in relation to the individuals and groups from the Catholic camp, who still preferred Bernolák's version of Slovak ${ }^{47}$ It is understandable that it could not fulfil this role in relation to the Czech intellectual environment, because J. Hollý did not figure in it as a recognized poet and

46 PÁCALOVÁ, ref. 33, p. 140. Another author also gives a similar evaluation of Hurban's biography of L. Štúr - as a biography that "fundamentally shaped the national historical canon and Śtúr's image in the memory of the Slovak public"; DEMMEL, ref. 10, p. 29

47 J. Butvin analysed their views and positions in detail. See BUTVIN, Jozef. Slovenské národno-zjednocovacie hnutie (1780 - 1848). (The Slovak national unification movement (17801848).). Bratislava: Vydavatel'stvo Slovenskej akadémie vied, 1965, p. 324, 325. On Štúr's views in this context see AMBRUŠ, ref. 26, p. 120-121. 
natural authority. However, in the course of long-term historical development, especially in the 20th century, the micro-narrative of Dobrá Voda 1843 gradually acquired further functions.

$$
* * *
$$

In his study Slovakia and its literary life, published as a series in Slovenské pohlady in the period 1846-1851, Jozef Miloslav Hurban stated that public and cultural life in Slovakia originally looked as if something like the Great Wall of China had been built between the two linguistic camps. In this way he wanted to indicate that the two groups of intelligentsia lived along side each other, but communicated only minimally. They usually ignored or competed with each other: "Each side gathered its strength, each sharpening itself and strengthening itselffor victory. [...] The Slovak Evangelicals thought that they had the complete truth, that the Czech language is more educated than the Slovak, and they had to do double the work because they also had to teach the language as well as other things. Bernolák's followers think they have the complete truth, when they can say with good consciences that Slovaks have to write in Slovak. But all this would be overcome, if only the religious narrow-heartedness, which prevented the brotherly embrace of the sons of one nation, could be removed from Slovak heads." 48

Regardless of the fact that that they sometimes shook hands across this Great Wall of China by means of isolated initiatives, which some members of the intelligentsia from both confessional and linguistic camps pursued ever more systematically, ${ }^{49}$ it is important to realize that what Hurban describes as religious narrow-heartedness in people's heads is nothing other than a typical feature of Slovak public life, namely traditional confessionalism, as analysed by Anton Augustín Baník. In connection with the situation in the first half of the 19th century, he stated: "[...] the Slovak national confessionalism of this period was still [...] not disturbingly sharp. It was not the evil that from the end of the 19th century pulled the Slovak nation like a dark cloud of confessional jealousy and from the beginning of the 20th century like the black smoke of power-political confessionalism". ${ }^{50}$

48 Cited according to the edition HURBAN, Jozef Miloslav. Slovensko a jeho život literárny. (Slovakia and its literary life). Bratislava: Tatran, 1972, p. 132, 133

49 Some concrete are given by BUTVIN, ref. 40, p. 94, 95, 114, 115. Information on the mutual contacts, support and co-operation as well as on the basic characteristics of relations between the two confessional or linguistic camps is given by RIŠKOVÁ, ref. 30, p. 495, 496.

50 BANÍK, Anton Augustín. O dialektickej podstate slovenského konfesionalizmu. (On the dialectic essence of Slovak confessionalism). Ed. Augustín Mat'ovčík. Martin: Vydavatel'stvo Matice slovenskej, 2000, p. 35. ISBN 8070905662. 
The main actors in modernization of the Slovak environment, especially L'. Štúr, understandably also had to deal with this phenomenon. Confessionalism and confessional particularism became a brake on the further development of Slovak society. They complicated the development of a feeling of national community and unity. This reduced the ability of the Slovaks to act in the coming social and political struggles. ${ }^{51}$

Mutual contacts, attempts to come closer and cooperate, search for consensus - all these initiatives or activities were actually efforts to reach beyond the wall or even attempts to dismantle it, in an effort to accelerate the formation of a nationally defined Slovak community. Essentially, it was a longer term process of overcoming mental barriers.

In the course of further historical development, the instrumentalized motif of overcoming mental barriers, present in the structure of the appropriate historical micro-narrative acquired the status of a symbolic gesture, which functioned as a norm-creating act, founding the social idea of the unity of the nation. At the same time, however, it implied the constant presence of Catholic-Protestant confessional duality, which was not regarded as a necessary evil, but - if we think in the framework of the primordialist understanding of the nation, as the Slovak patriots of the 19th century did even if they did not directly realize it - as a natural part of the national "organism".

Such a gesture must be not only sufficiently transparent, readable, communicated through the media and if possible constantly reproduced in the form of symbolic representations, which were/are spread among the population. It also had to be acceptable and accepted in both confessional environments as a clear and undoubted expression of inter-confessional consensus.

The importance of the micro-story Dobrá Voda 1843, which is placed in the framework of the greater national narrative, also lies in its educational and socializing function. By means of it, pupils, students and others acquire concrete knowledge about the past, which shapes the rational and emotional pre-conditions for identification with a particular publicized version of the past as The National History. However, in my view, this is more a secondary matter. I see the primary importance of this micro-narrative in the idea that it teaches us to be Slovaks, or to be more exact it teaches us to be members of a Slovak nation as a bi-confessional community. ${ }^{52}$

51 For more details see the study, ŠKVARNA, Dušan. L'udovít Štúr a modernizácia slovenskej spoločnosti pred rokom 1848. (L'udovít Štúr and the modernization of Slovak society before 1848). In Studia Academica Slovaca 44. Prednášky 51. letnej školy slovenského jazyka a kultúry. Eds. Jana Pekarovičová, Miloslav Vojtech. Bratislava: Univerzita Komenského v Bratislave, 2015, p. 84. ISBN 9788022339155.

52 It is necessary to understand this statement more as a figurative expression: This (or any other) 
In the socialization process, every child or student grows up into a national culture. He or she adopts the national culture and becomes a member of the national community. This also includes the culture of inter-personal relations, social communication, collective memory or social imagination. This process is part of the integration of the young person into the adult world, into a community that is primarily defined nationally. This obviously does not mean that adults are not participants in a similar process.

In other words, the verifiability of facts and details, which concerns the positivist oriented historian, the actual description of the story of the visit of Štúr and his two friends to Hollý, are secondary matters in this micro-narrative. The much more important thing is the timeless message carried by the thematization and medialization of this micro-story. This message, which is part of the construct of national history, and which also helps to shape and maintain this construct, is the basic axiom of modern Slovak nationalism. It is an essential expression of the national idea in the Slovak environment, because it "teaches" us that the national phenomenon is a result of inter-confessional consensus, which must be constantly renewed. It is only understandable that today this organizational element of social imagination has weakened as a result of secularization, declining influence of church structures and reduced confessional profiling of culture in public life. However, we should not forget that during the whole of the 19th century and at least the first half of the 20th this phenomenon represented an important part of social life in Slovakia.

Thus, Dobrá Voda 1843 is not only an emotionally attractive, touching story with a dose of pathos, which still makes it worth going on a nice trip to the poet's grave and memorial room. It is also a narrative with a more universal message. In my view, it also functions as a medium bearing important "genetic" information about the essence of Slovak nationalism. The adjective "genetic" is not exact in this context but a little misleading, because it associates the image of the nation as a living organism and does not adequately reflect the fact that national identity is mainly a culturally and socially conditioned phenomenon, in other words, a construct. However, if we want to remain faithful to this rhetoric and terminology, then we could compare the distribution of the micro-narrative Dobrá Voda 1843 among the general population of Slovakia to the vaccination of an organism, which is expected to produce antibodies to the "harsh" influence

instructive story from history does not teach or educate us by itself. This is done by people such as teachers and writers or by such people operating in the framework of institutions, systems or media, including schools, propaganda, the press, television and so on, which apply such narratives to target groups such as pupils or the whole population, promoting specific, deliberately shaped and structured images or stories from history with the aim of influencing or directing the identity or loyalty of members of a given social group. 
of confessional particularism as a result of this medical intervention. Perhaps the literary and publicist texts about the visit of Štúr's group to Dobrá Voda do not always enable such an interpretation as I have given above, but Kováčik's picture from 1935 is more or less unambiguous in this direction: It offers its viewers an idea of the Slovaks as a bi-confessional national community.

Clearly, we will never know what was the basic impulse for the decision of Štúr and his two friends to visit Hollý at Dobrá Voda. Was it initially only a private visit with the aim of finding out Hollý's view or getting advice from him, or did they realize its symbolic potential as a historic event relevant for the formation of national ideology and identity? Or were they aware of the symbolic aspect of the visit from the beginning, already expecting its public propagandist use in connection with the codification of the new version of standard written Slovak?

Regardless of their original motivation, the micro-narrative Dobrá Voda 1843 does not give us only a picture of the individual experiences of the participants of this visit or specifically of Hurban, who described it. It brings us - today's consumers of the textual, artistic or filmed depiction - the act of meeting of members of the two different confessional and linguistic camps, which can be "read" as deliberate or planned overcoming of mental barriers from the point of view of the formation of national unity and identity. It passes on the symbolic gesture of "our" ancestors, worthy of continuation in the building of a consensually created community.

We could probably express the original "reading" of this micro-narrative in the following sentences: Štúr and his followers, members of the Protestant community, visited the Catholic priest and most important poet of the so-called Bernolák school Ján Hollý with the aim of gaining his agreement to the introduction of a new form of standard written Slovak. Since the poet was a natural authority not only for them, but also for Catholic intellectuals, they decided to promote the codification with precisely this symbolic act.

Compared to the original instrumentalization from the 1840s, some degree of shift or up dating can be identified: While the original codification was supported by the name and symbolic acts of Ján Hollý (his agreement and blessing), today, the symbolic act is regarded more as the actual ritual meeting of Štúr and followers with Hollý as a prefiguration of the overcoming of confessional limitations and the creation or preservation of national unity. This micro-narrative does not legitimize the standard written language, which is already taken for granted, but national unity itself.

This change in the narrative strategy is connected with a reconfiguration of the collective memory: In the older version of the micro-story, the relationship of Štúr and his associates to Hollý was presented and reflected as subordinate. 
This basic characteristic is also articulated in various ways in different texts, for example, by emphasizing the age difference between old Hollý and the young group associated with Štúr, by means of the metaphorical father - son relationship or a deliberately constructed image of Hollý as the great teacher and Štúr's group as his spiritual pupils.

In the course of the 20th century, Slovaks increasingly came into contact with this micro-story, from 1935 also with its visual version created by A. Kováčik. The picture suggested more a co-ordinated structure of relations between the participants, who appear as equal partners, as symbols representing their confessional groups.

Further symbolic pairs embodying confessional parity in a nationally defined community, inter-confessional co-operation and supra-confessional national unity also functioned and still function in the collective memory of the Slovaks and in Slovak public life. First of all there are the social models of the era of the first Matica Slovenská in the 1860s and 1870s, namely the Catholic Bishop Štefan Moyses and the Evangelical Superintendent Karol Kuzmány. The established symbols of the inter-war period, especially in relation to the debate on autonomy, are two politicians - the Catholic priest Andrej Hlinka and the Evangelical pastor Martin Rázus. However, these paired symbols are typically emblematic and static. It is possible to say that they lack a more significant narrative component. They are not linked by emotionally graspable stories, comparable to that available for the symbols of Šturr, his followers and Hollý. ${ }^{53}$ In spite of this, they were used in the inter-war and war periods in Slovak public life, including politics and propaganda.

The question of whether the micro-narrative Dobrá Voda 1843 worked in a deliberate and systematic way can be answered only by more detailed research. However, in each case, the political or social elites of the time realized the importance of personal symbols as social models, and they gave them the role of legitimizing instruments in the context of their political and ideological conceptions.

For example, this applied to a full degree to the leading figures in Matica Slovenská, although they preferred the symbolic pair: Moyzes - Kuzmány. The micro-narrative Dobrá Voda 1843 reached not only the expert public, but also the publicist and artistic sphere. Ordinary citizens also gradually began to be aware of its symbolic importance. Two concrete examples from the period of the Slovak state can be given to illustrate this.

53 Emotionally satisfying micro-stories are understandably linked with Rázus and Hlinka as with independent symbols functioning at the meeting point of confessional and national identification. 
Firstly, I will point to a specific source, the scenario of the literary - dramatic programme Steps in Slovak history broadcast by Bratislava radio on 12 March 1940 , that is two days before the first anniversary of the origin of the Slovak state. It was written by Ladislav G. Fagul'a and directed by Emil Rusko, who also played the part of L'udovít Štúr. The scenario captured the historical development of Slovakia through a great span of time - from Pribina to the Slovak state. The whole programme is presented as a conversation between father and son, with the father informing his son about the historical development of the Slovak nation, passing on the national story. The author put into the scenario various historical events or micro-narratives about these events and personalities, which he considered of key importance, for example, the co-operation of Moyzes and Kuzmány during the Matica Slovenská era, the First World War and the origin of Czechoslovakia, the funeral of Andrej Hlinka and the origin of the Slovak state.

Fagul'a gave the contact of Štúr's group with Ján Hollý an important role in the centuries of historical development: "[...] and when 900 years had passed since the loss of Slovak statehood and independence [of Great Moravia - P. M.] it happened that the nation was suddenly revived by an elderly priest and poet Hollý, who was Catholic, and a young Bratislava student Štúr and his friends, who were Evangelicals. They were the only light for the Slovaks a hundred years ago". ${ }^{54}$

The author of the scenario was clearly inspired by Hurban's version of the micro-narrative Dobrá Voda 1843, originally published in his biography of Štúr in the $1880 \mathrm{~s} .{ }^{55}$ However, some statements or quotations from Stúr's writings and newspaper articles are also identifiable in the dialogue between Hollý and Štúr, which do not occur in Hurban's text directly in his account of the visit to Dobrá Voda. The author cannot be blamed for this fact. He was not writing a factographic historical work but a text on the boundary between documentary and artistic writing. When Štúr persuades Hollý that the basis for the standard written language can only be the Central Slovak dialect, because "in the depths of the Tatras it was the most protected from foreign influnences", Hollý argues that in contrast to the Western Slovak codified by Bernolák, this dialect has not been scientifically studied and systemized in its grammar. ${ }^{56}$ In the end, however,

54 Archív Slovenského rozhlasu Bratislava (hereinafter A SRo). Written documents - FAGULA, Ladislav G. Kroky slovenských dejín. (Steps in Slovak history). Scenár, Copy of a typescript (1940), p. 2.

55 This is shown not only by the method of argumentation about Hollý and Štúr as literary figures, as well as the formulation of some of the sentences in the scenario, for example, the use of a double negative in one of Štúr's questions, as I pointed out above in the context of an attempt to analyse the rhetorical strategy of J. M. Hurban as a witness and direct participant in the visit to Dobrá Voda.

56 L. G. Fagul'a uses the word nárečie with its present meaning, namely dialect, although in his 
he accepts Central Slovak as the basis for the new codification, and the scenarist puts in his mouth a slightly changed sentence taken from Hurban's text: Hollý agrees with Štúr because allegedly: "the folk songs are most beautiful in the Upper Slovak speech”. However, L.G. Fagul'a formulates Hollýs approval of the new form of the standard written language unambiguously, deviating in this from the source, namely Hurban's text. This appears to have been motivated not only by the dialogue form of this literary genre, but probably also by national ideological and patriotic educational considerations reaching beyond merely literary aims. To Štúr's question: "So you don't object at all to our enterprise?", the poet replies with an openly and unambiguously positive statement: "On the contrary, I'm delighted that you're showing the nation the way it can advance to its flowering." Then he gave Štúr and friends his blessing: "May the Lord God help you in this. " ${ }^{57}$ In harmony with Hurban's interpretation, the reader or listener could not perceive this as anything other than a national act.

We do not know and will presumably never find out exactly what Hollý and Štúr really said to each other, what thoughts and arguments came from one side or the other, but it is very probable that at least some of them were similar to those L. G. Fagul'a put into the mouths of the actors on the basis of Hurban's testimony, but naturally with the exception of Ján Holly's unambiguous agreement with the codification of Central Slovak.

Although members of today's academic community express critical views on this key element in Hurban's narrative, and state that Hollý did not unambiguously agree with the new form of standard written Slovak, it is necessary to realize that in the middle of 1940 such expert views had not been articulated and so they did not resound in public discourse. On the contrary, the author of the scenario and director accepted the fact that Hurban's biography of L. Štur significantly contributed to the formation of the national historical canon and the alleged agreement of Hollý with Štúr's conception was accepted as a historical fact. They had no reason to doubt it, quite the reverse, it suited them for national ideological reasons: It had a significant place in their literary or dramatic story, which had socializing and educational as well as entertainment aims.

From this point of view, the joint artistic-documentary work of L. G. Fagul'a and E. Rusko can be placed among the links in the imaginary chain of various expert, publicist and artistic products, which mediated to the general public the Dobrá Voda 1843 micro-narrative within the intentions of Hurban's interpretation.

works, Štúr designates the Slovak language itself as a nárečie, as in his text: Nárečja slovenskuo alebo potreba písaňja v tomto nárečí. (The Slovak nárečie or the need to write in this nárečie).

57 A SRo, FAGULA, ref. 54, p. 3, 4. 
Although the accompanying commentary to this micro-story in the framework of Fagul'a's scenario strikingly emphasizes the great age difference between Hollý and Súr with associates - the old man versus young students - to some degree shifting the idea of the subordinate relationship between these symbolic figures, the actual event, which centres on the moment of meeting in the priest's house at Dobrá Voda is shaped and structured in such a way that the final picture suggests a co-ordinating relationship.

Apart from the polite phrases, the conversation between Štúr and Hollý is conceived on the literary-dramatic level as a rational exchange of views. Štúr behaves to Holly with extraordinary respect, but otherwise his position is self-conscious: He is not speaking in the name of a small group of Bratislava students, but of the whole of Slovakia. Šturr: "We came to ask about the health of our dear master and assure him of the love the whole of Slovakia feels for him. " It is interesting that he addresses Hollý with the word Master, which is taken from Hurban's text: "Then we undertook a joint trip to the master of Slovak poets, Holly' at Dobrá Voda." Regardless of whether the author of the scenario knew, for example, the salutation from the Bratislava students addressed to Hollý in June 1843, which addressed the poet as Father of the Slovaks, he used an unauthentic form of address, which we find in Hurban almost 40 years after the visit to Dobrá Voda. However, it helped the scenarist to give both figures the same status in the national movement, to bring them close together as equally valued symbols. In their own ways both ruled by the word, both were masters of the word - Hollý as a poet, Štúr as a linguist and codifier. Moreover, apart from insignificant exceptions such as the invitation to lunch from the master of the house Father Lackovič, the whole exchange occurs between Štúr and Hollý. Hurban and Hodža are entirely silent in this dramatization, not saying a word. Thus, the strategy of the writer is clearly directed towards making Štúr and Hollý not not only the dominant figures in the micro-narrative as presented in this literary-dramatic work, but also to place them on the same level as equal symbols with a co-ordinative relationship between them. The message of a story structured like this lies not only in the transmission of the idea that members of the Evangelical and Catholic intelligentsias participated equally in the creation of standard written Slovak - the basic attribute of national identity. Since Hollý and Štúr function here as representative figures symbolizing the Catholic and Lutheran components of Slovak society, listeners could also understand the micro-narrative Dobrá Voda 1843 in its radio version as a message from "our" forebears inspiring us to seek inter-confessional consensus in the current public and political life of the Slovak state. The co-ordinative or subordinative structure of the micro-story Dobrá Voda 1843 could contribute to generating two different, politically usable variants of the message: the birth of standard written Slovak against the back- 
ground of the consensus of two equal confessional components - Catholics and Evangelicals, or against the background of emphasis and acceptance of the priority or dominance of one confessional component of society over the other. Some indications suggest that contemporaries were aware of these two different versions of the message and their current political-ideological significance. I will leave open the question of whether the specific shaping of this story was motivated by the interests and aims of the regime or the emerging opposition. ${ }^{58} \mathrm{In}$ the end, the symbolism of this micro-narrative did not have a central place in the interests of the ideologues and propagandists of the time. They struggled more over other symbols - Milan Rastislav Štefánik and Andrej Hlinka.

$$
* * *
$$

However, the second case I will give here confirms the hypothesis I have outlined. It is the view of an appropriate individual, formulated as a letter addressed to the editorial office of the monthly Služba (Service) published by the Štúr Evangelical Society. We can interpret it and this was how the editorial office understood it - as the "voice of the people" calling for application of the message of the micro-narrative Dobrá Voda 1843 in the current public - political life of Slovakia. The writer of the letter saw this as the message of "our" great forebears, as instructions for real action in the present. The fact that the editors published it in 1940 immediately in the first issue of Služba entitles us to consider that the writer was reacting to the situation and atmosphere in society in the previous year - $1939 .{ }^{59}$

The two following events also had influence here: the chairman of the Štúr Evangelical Society, Bishop Samuel Štefan Osuský and General Bishop Pavol Vladimír Čobrda participated in the commemoration of Štefánik on Bradlo organized by the Union of Evangelical Youth in May 1939. The event represented a mass, spontaneous protest against the national memory policy of the Ludák regime. Prime Minister Jozef Tiso endeavoured to put pressure on the organizers of the planned ceremonial unveiling of a monument to Štúr in Modra. Tiso wanted to ensure that the celebrations did not include the inauguration of a new

58 From this point of view, it would be interesting to analyse and compare, for example, the official and unofficial celebration culture connected with the centenary of the origin of standard written Slovak in 1943 and the 80th anniversary of the Memorandum of the Slovak Nation in 1941. In this context, I point again to the decision of the Štúr Evangelical Society not to participate in the government celebrations of the centenary of standard written Slovak, but to organize its own event at which Daniel Rapant gave a lecture.

59 For more details see the publication: MACHO, Peter. Milan Rastislav Štefánik $v$ hlavách a v srdciach. Fenomén národného hrdinu v historickej pamäti. (Milan Rastislav Štefánik in heads and hearts. The phenomenon of a national hero in the historical memory). Bratislava: Historický stav SAV, 2011, p. 114 etc. ISBN 9788089396139. 
building for the Evangelical orphanage and that S.Š. Osuský did not give an official speech at the monument to Štúr. In the end, government circles banned the unveiling of the Modra monument. ${ }^{60}$

Thus, by coincidence, in the same year that the radio broadcast a literary drama series Steps of Slovak History, the monthly Služba published a short contribution, namely a letter from a small farmer in the village of Podbranč near Senica.

Reacting to the events of 1939, the writer Pavel Kadlečík described the impressions he got from visiting the local church school: "I recently visited the Ev[angelical] school. My attention was attracted by the older and more recent pictures. One of the pictures made me think deeply. It was a picture of the visit of the three great Slovak patriots Šturr, Hodža and Hurban to that fourth great patriot Ján Hollý at Dobrá Voda in the year forty-eight. Looking at this picture took my thoughts back to the distant past, when the Slovak nation was suffering in the bitter servitude of harsh Magyarization, the years of deepest darkness when the spark of hope for better times was only weakly flickering! These three men, written with golden letters into the history of the Slovak Evangelical Church and the whole nation, went to the Catholic priest Hollý. Hodža came from far-away [Liptovský] Mikuláš, Hurban from Hlboké and Štúr from Prě́porok [Bratislava] not regretting the time or the effort. They went to discuss how to help their poor nation without distinction of religion." 61

Pavel Kadlečík asked how was it possible that in the time of the greatest national oppression Catholic - Evangelical cooperation functioned, but now, in a time of freedom, after the origin of the Slovak state, it did not. He emphasized that even Štúr's well known and frequently used slogan: "Retreat impossible, we must advance" did not correspond to the current state of society: "Both our confessions cannot accept tolerance, because we are going backwards."

On the other hand, he appeals to the elites of the time to learn from the past: "May the visit to Ján Holly be a lesson for those who do not want to understand the spirit of the time and do not want cooperation in the nation. Correction is necessary from the top. If it comes the people will easily adapt. Whoever succeeds in bringing about this coming together will lay a brick in the building of a free Slovakia and contribute to the development of the Slovak nation in every direction. There has been enough lack of understanding. Let the day of a happy life shine at last. Let the visit to Ján Hollý be a model for us!"62

The letter was accompanied by an explanatory note from the editors: "We received these lines from a poor, simple small farmer from Podbranč with only 6 classes at elementary school. We are publishing them as a stimulating example

60 MACHO, ref. 59, p. 125-126, 158-160.

61 KADLEČÍK, Pavel. Obraz. (A picture). In Služba, 1940, year 4, no. 1, p. 26-27.

62 KADLEČÍK, ref. 61, p. 27. 
and proof of the maturity of our Ev[angelical] Slovak people on national matters. " 63

It is highly probable that the picture mentioned by the writer of the letter represented Kováčik's version from 1935, but it is not clear whether he had in mind a classic framed picture decorating the school premises or a special classroom illustration.

The text of the letter contains various inaccuracies and mistakes, which show that P. Kadlečík had a strongly idealized and schematized idea of the visit to Dobrá Voda. However, he stated to the readers of Služba a version of the micro-narrative Dobrá Voda 1843 showing a coordinative structure with all four - Štúr, Hurban, Hodža and Hollý - meeting to discuss national affairs as equal partners. It is questionable whether he could have gained his feelings, impressions and facts only on the basis of seeing the picture he mentioned once. I think that he carried long-term knowledge of this meeting in his head, and a chance encounter with the picture in the premises of the church school functioned only as trigger or catalyst, which activated older layers of his individual memory.

We are informed by the editors about Kadlečík that he was a simple small farmer who had attended only six classes of elementary school. We have no other biographical information. We do not even know his age, so we do not know when he received his school education, and whether he was influenced by school lessons in the period of the First Republic. We can only guess what factors of nationalist indoctrination could have influenced the process by which he appropriated particular images and stories from national history. Symbolic representations spread by means of the press, societies and festivals come into account. I will mention in particular, the fact that the Slovak National Society (Národný spolok slovenský) and its local branches were active in the part of western Slovakia from which the author came. Their symbolic agenda included Ján Hollý and Štúr's group.

\section{$* * *$}

The oil painting The visit of Štúr, Hurban and Hodža to Ján Hollý at Dobrá Voda in July 1843 is undoubtedly the most important and extensive of Kováčik's works with a historical theme. The painter showed it to the Slovak public for the first time in September 1935 at an exhibition of his works in his Bratislava studio.

The space in which the artistic composition is placed is similar to that on the canvas depicting the establishment of the Slovak Learned Society (Slovenské učené tovarišstvo), which the artist had painted the year before. It is a smaller,

63 KADLEČÍK, ref. 61. 
modestly furnished room containing chairs, a writing table, unidentified books, a goose quill and inkpot, but also a crucifix, from which it is possible to deduce that the moment captured by the picture is located in a priest's house. The light penetrating into the room through a window falls mainly in the centre of the picture onto the books and the cross. These illuminated artefacts undoubtedly embody education / culture and Christianity, the two basic pillars of the Slovak national movement. Both symbols are placed not only in the geometric centre of the whole picture, but also in the symbolic centre of the composition, between the figures of Ján Hollý and L'udovít Štúr. In this context, they can also be understood as the sources from which both the main Christian confessions drew for their development.

The first impression we derive from a superficial view of Kováčik's picture is one of immobility or staticness with the figures sitting or standing. Štúr stands with legs apart turned towards the seated Hollý. His pose is self-confident, the gesture of his hands show that he is convinced of the correctness of the solution he proposes and is intensively presenting to the other people present, especially Hollý. A detailed examination, which is possible only if we have in front of us a large copy of Kováčik's picture, will show that the expression on J. Hollý's face shows more unease, while the facing seated figure of M. Lackovič is thinking deeply about the arguments he is hearing. The only movement we can see or guess in the picture is the movement of Štur's lips. If we understand the event - the primary basis of history - as movement in time and space, then Kováčik's work represents a specific type: verbal communication.

When researching Kováčik's papers in the Archive of Fine Art of the Slovak National Gallery, I did not succeed in finding an answer to the question of the basis, prototypes or models, which inspired the artist to create this work. However, it is highly probable that he also reached for the biography of L. Štúr published in the 1880s in the pages of Slovenské pohl'ady where Hurban described the visit of Štúr and his two friends to Hollý at Dobrá Voda.

It is also noteworthy that when describing the Dobrá Voda episode, Hurban himself did not mention a visit (návšteva) or a pilgrimage (pút'), as he did in connection with the mentions of the frequent pilgrimages of Štúr's group to Madunice, but a trip (výlet).

While a trip has more an entertainment/relaxation character and a pilgrimage has a symbolic/sacred dimension, a visit may appear to be an ordinary, relatively everyday matter. However, in reality it is one of the oldest activities of the human species. It involves a fixed set of ritualized practices, a symbolic - ceremonial form of human behaviour and inter-personal communication: The guests come for a visit, usually with a gift, the master of the house seats and entertains them. In this context, we can ask the logical question of what gift did Štúr and his two 
friends present to J. Hollý. The answer seems to be simple: news of the decision to adopt a new form of standard written Slovak.

If Štúr, Hurban and Hodža are guests on a visit, we are justified in asking why the master of the house has not seated them. There are only two seated figures in the picture - J. Hollý and M. Lackovič - the hosts, not the guests. The apparently paradoxical depiction can be explained only by the painter granting the "privilege" of sitting to members of the older generation. A superficial view may suggest that the artist is showing a preference for the Catholic priests and emphasizing their dominance - the Catholic participants are shown sitting, while the Protestants are standing. Such an understanding is possible if we consider only the horizontal and vertical levels of the composition. However, if we also consider the depth of the picture, namely the spatial arrangement on the front - back axis, we will see that the painter has placed two figures in front: the seated Catholic Hollý and the standing Evangelical Šturr, while all the other personalities in the picture are placed in the background of the composition regardless of their gestures at the given moment.

Hurban's rhetorical strategy when creating this micro-story rested on two constitutive elements, which I already analysed in the previous parts of the study: The first was the alleged agreement of J. Holly to the introduction of the new standard written language; the second was the blessing that Hollý granted to Štúr and his friends. These two elements are inseparably combined in Hurban's narrative and jointly shaped the ideologized picture of Hollý. Such a structured or if we prefer "constructed" image of Hollý as an agreeing and blessing authority, functioned in the 1840 s in the role of a legitimizing and "propagandist" instrument in the struggle to establish the new standard written Slovak.

However, Kováčik's oil painting from 1935 in a sense recoded the message of Hurban's micro-story. In this context, we cannot overlook the fact pointed out by the historian Daniela Kodajová: that in the framework of collective memory, Śtúr was only really put in the symbolic position of leader of the national movement from 1935, when Matica Slovenská organized celebrations of the 120th anniversary of his birth. According to Kodajová, other images of Štúr had prevailed until then, for example, of Štúr as a teacher of the young. ${ }^{64}$

Thus, 1935 was not only the year of the origin of Kováčik's oil painting and the exhibition in his studio, we can also say, although with some exaggeration, that Štúr began a new posthumous symbolic career in that year. In his picture

64 KODAJOVÁ, Daniela. Oslavy Ludovíta Štúra ako médium formovania historickej pamäti Slovákov. (Celebrations of Ludovít Štúr as a medium in the formation of the historical memory of the Slovaks). In MACHO, Peter - KODAJOVÁ, Daniela et al. Ludovita Štúr na hranici dvoch vekov. Život, dielo, doba verzus historická pamät'. Bratislava: Historický ústav SAV in VEDA, vydavatel'stvo SAV, 2015, p. 198. ISBN 9788022414548. 
and its creative composition, A. Kováčik was probably reacting to this change or shift of interpretation by placing the figures of Hollý and Štúr in the foreground of his historic canvas. In Hurban's narrative-verbal version the main symbol was Hollý, but in Kováčik's visual interpretation there are two main symbols: Hollý and Štúr. Hurban's original micro-story gained a slightly different meaning when "retold" by Kováčik's brush. As we already said, in Hurban's older version of this micro-story, the relationship of Štúr and his followers to Hollý was presented and reflected as subordinate. However, Kováčik's picture suggests a more coordinative structure to the relationship between Hollý and Štúr, who are presented as equal partners representing their confessional communities: Catholics and Protestants. They embody inter-confessional cooperation and supra-confessional national unity, contributing to spread of the social idea of the Slovak nation as a bi-confessional community. Clearly, such a "reading" of Kováčik’s picture depends first of all on the specific individual, his education, mental ability and so on. In this context I will point to the fact that the analysed micro-narrative and so also the analysed work of art, clearly do not provide information of a quantitative nature, namely on the Catholic majority versus Lutheran minority in the Slovak population and the consequences for the public life of society. On the contrary, it provides information about the qualitative and symbolic aspect of the codification and nation forming process with an ideologized message, namely the cooperation, consensus and equality of the two main confessions.

In the end, however, the interpretative shift was also reflected on the verbal level of the micro-narrative Dobrá Voda 1843: the described or painted event is no longer reflected exclusively as a visit, but ever more frequently as a meeting. This is not only a mere play with words, but concerns the fact that the expression meeting corresponds much better to the above mentioned coordinative structure.

Ludovít Štúr himself is dominant among the famous group of three: Štúr Hurban - Hodža in Kováčik's oil painting, while the placing of J.M. Hurban and M.M. Hodža in the background suggests that the pastor from Hlboké was only an episodic person in the codification process. This placing of the figures in the picture flowed from Hurban's original efforts to emphasize Štúr's importance in this stage of the national movement, but it does not correspond entirely to the real importance and role of Hurban in the establishment of standard written Slovak. It is not necessary to forget that in his biography of Štúr, Hurban himself interpreted the codification and introduction of the new standard written language as a collective act. However, it was precisely Hurban, who really began to introduce Štúr's version of Slovak into public life in the second issue of the annual literary almanach Nitra in 1844, and it was precisely Hurban who carried on the most intensive polemic struggle against the opponents of the Slovak language. 
From 1935 ever more inhabitants of Slovakia came into contact with the visualized version of the story of the visit to Dobrá Voda, partly as a result of the spread of reproductions of Kováčik's work of art. At first, people could encounter the original only at art exhibitions, but it was soon reproduced not only in the periodical press and in books, but also in the form of pictures in schools. However, in the following years and decades, the micro-narrative Dobrá Voda 1843 also appeared in radio, film and television versions. Thus, it was also spread by media that worked not only with words, but also with images and sound. The most wide spread and continual method of distribution of this micro-narrative in both verbal and visual form was and still it its presence in school textbooks. Today we can also find this pictorial motif on the covers of various publications, on posters and even in miniature form on bookmarks produced by Matica Slovenská. Its exclusiveness derives from the fact that apart from Kováčik's picture, we do not have any other works of art that capture in visual form the moment of meeting of Štúr and his two friends with Ján Hollý in the priest's house at Dobrá Voda.

* This work was supported by the Agency for Supporting Research and Development on the basis of contract no. APVV-14-0644 Continuities and discontinuities of political and social elites in Slovakia in 19th and 20th centuries at the Institute of History of the Slovak Academy of Sciences. The text also originated on the basis of research done in the framework of the project of the Institute of History of the SAS on Jozef Miloslav Hurban and his relations in the context of the national movement and historical memory.

\section{Historisches Mikronarrativ als Mittel zur Formung der kollektiven Gedächtnisses und Identität}

Symbolisches und ideologisches Charakter des Besuches der Anhänger Štúrs bei Ján Hollý in Dobrá Voda

\section{PETER M A C H O}

Die Studie untersucht das historische Mikronarrativ darüber, wie sich die drei Anhänger Štúrs, die Repräsentanten der Protestanten-Kommunität, mit J. Hollý, dem bedeutendsten Dichter seiner Zeit der die katholische Intelligenz repräsentierte, getroffen haben. Sie beinhaltet das Motiv des Entstehens der Schriftsprache als des Grundattributes der slowakischen Nationalidentität auf dem Hintergrund des Konsensus zwischen der katholischen und lutherischen Komponente der Gesellschaft. In den 40. Jahren des 19. Jahrhunderts erfüllte dieses Mikronarrativ die Funktion der Legitimation, es heiligte symbolisch die Sprach- und Nationalkonzeption von L'udovít Štúr. Im Laufe des 20. Jahrhunderts begann es eine neue Funktionen zu erfüllen, vor allem die Edukations- und 
Sozialisierungsfunktion. Im Wesentlichen trug es zur Verbreitung der sozialen Vorstellung über die slowakische Nation als einer zweikonfessionellen Gesellschaft bei. Ein Teil der politischen und kulturellen Elite hat sich bereits in der Zwischenkriegszeit die Symbolik der Begegnung von Štúr und Hollý angeeignet und nutzte sie für Legitimierungs- und Propagationszwecke, für die nationalistische Mobilisation. Im 20. Jahrhundert hat sich das erwähnte Mikronarrativ unter die Gesellschaft auch dank modernerer Medien verbreitet (Rundfunk, Fernsehen). Die visuelle Wahrnehmung und die Massenperzeption startete jedoch bereits im Jahr 1935 der akademische Maler Andrej Kováčik mit seinen Ölgemälden, welche es in reproduzierter und verkleinerter Form auch in die Lehrbücher schafften.

Mgr. Peter Macho, PhD.

Historický ústav SAV

P. O. BOX 198, 81499 Bratislava, Klemensova 19

e-mail: peter.macho64@gmail.com 


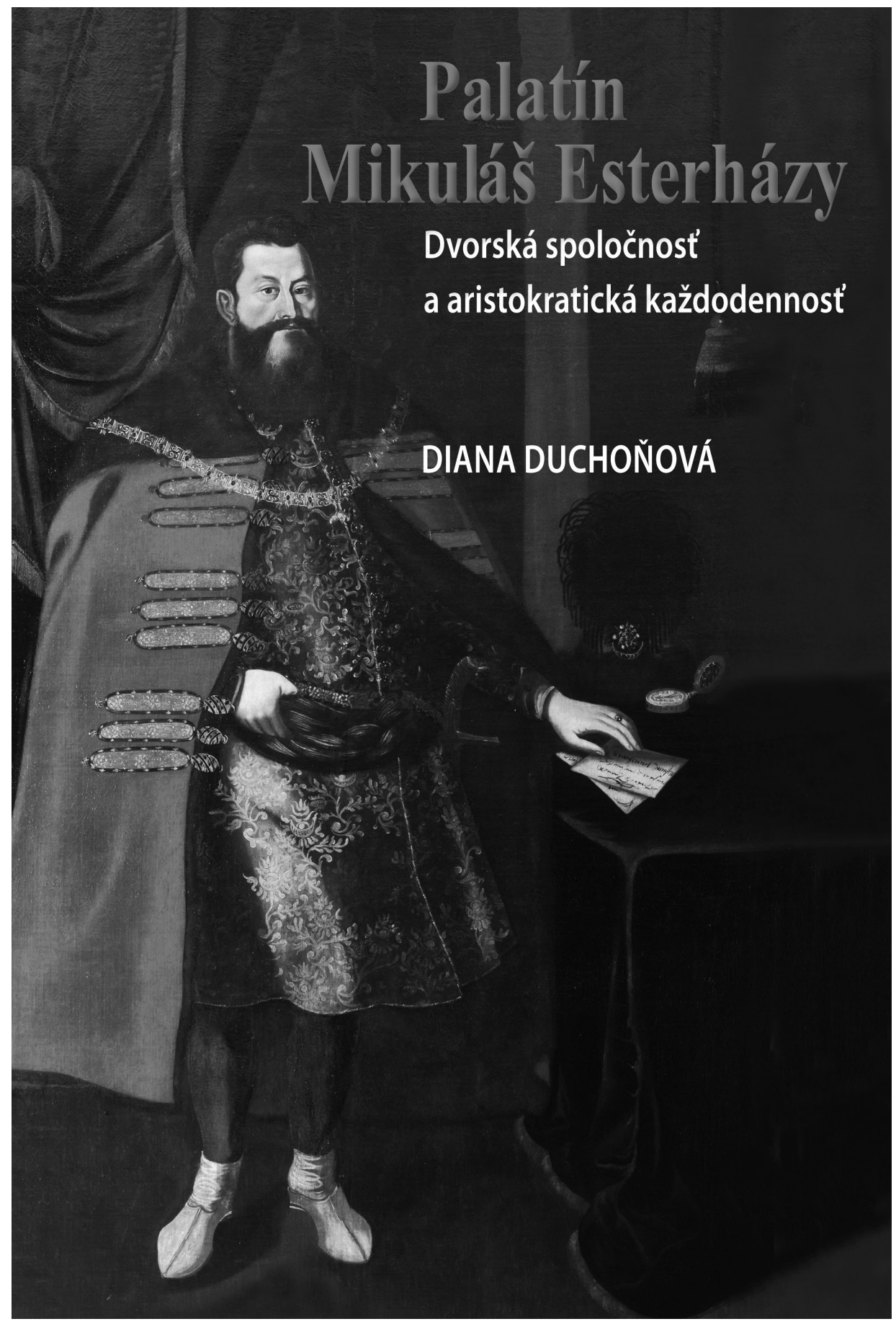

